PRINT ISSN 1119-8362

Electronic ISSN 1119-8362
Full-text Available Online at https://www.ajol.info/index.php/jasem http://ww.bioline.org.br/ja

\title{
Evaluation of Petrophysical Parameters of Reservoir Sand Wells in Uzot-Field, Onshore Niger Delta Basin, Nigeria
}

\section{*OMOJA, UC; OBIEKEZIE, TN}

\author{
Department of Physics and Industrial Physics, Nnamdi Azikiwe University, Awka, Nigeria. \\ *Corresponding Author Email: uc.omoja@unizik.edu.ng
}

\begin{abstract}
Evaluation of the petrophysical parameters in Uzot-field was carried out using Well log data. The target for this study was the D3100 reservoir sand of wells Uz 004, Uz 005, U008 and Uz 011 with depth range of 5540ft to $5800 \mathrm{ft}$ across the four wells. Resistivity logs were used to identify hydrocarbon or water-bearing zones and hence indicate permeable zones while the various sand bodies were then identified using the gamma ray logs. The results showed the delineated reservoir units having porosity ranging from $21.40 \%$ to $33.80 \%$ indicating a suitable reservoir quality; permeability values from $1314 \mathrm{md}$ to $18089 \mathrm{md}$ attributed to the well sorted nature of the sands and hydrocarbon saturation range from $12.00 \%$ to $85.79 \%$ implying high hydrocarbon production. These results suggest a reservoir system whose performance is considered satisfactory for hydrocarbon production.
\end{abstract}

DOI: https://dx.doi.org/10.4314/jasem.v25i2.5

Copyright: Copyright $\odot 2021$ Omoja and Obiekezie. This is an open access article distributed under the Creative Commons Attribution License (CCL), which permits unrestricted use, distribution, and reproduction in any medium, provided the original work is properly cited.

Dates: Received: 12 December 2020; Revised: 26 January 2021; Accepted: 12 February 2021

Keywords: Petrophysical parameters, porosity, permeability, hydrocarbon saturation, Niger Delta Basin.

Petrophysical properties such as porosity, permeability, fluid saturation and thickness of a reservoir are vital to oil and gas industry. The evaluation of these parameters enhances the ability to predict abnormally pressured zones, to estimate hydrocarbon reserves and reservoir bed thickness, and to distinguish between gas, oil and water bearing strata, by observing their electrical resistivity and relative permeability values (Hilchie, 1990; Schlumberger, 1996; Uguru et al., 2002). The Niger Delta Basin which consists of three litho- stratigraphic units all of which are strongly diachronous (Doust and Omatsola, 1990; Short and Stauble, 1967; Avbovbo, 1978) is situated at the North Eastern margin of the Gulf of Guinea on the West coast of Africa. These units include the Akata Formation, Agbada Formation and The Benin Formation. The Akata Formation is composed of marine shales and form the main source rocks for petroleum. The Agbada Formation is the hydrocarbon-prospective sequence in the Niger delta, where the sand serves as reservoirs and shale as the source rock (Doust and Omatsola, 1990). The Benin Formation comprises the top part of the Niger Delta clastic wedge, from the Benin-Onitsha area in the north to beyond the present coastline (Short and Stauble, 1967). Petroleum occurs throughout the Agbada Formation in the Niger Delta clastic wedge. Although the distribution of hydrocarbons is complex, there is a general tendency for the ratio of gas to oil to increase southward within individual depobelts (Doust and Omatsola, 1990). Stacher (1995) developed a hydrocarbon habitat model based on sequence stratigraphy of some petroleum-rich belts within the Niger Delta area, and provides a short summary of basin, trap, reservoir, and source rock and hydrocarbon character. Gas to oil ratios within reservoirs were reported by Evamy et al. (1978), Ejedawe (1981) and Doust and Omatsola (1990). Reservoirs occur along northwest-southeast "oil rich belts" and along a number of north-south trends in the Port Harcourt area. Tuttle et al. (1999) suggest that belts roughly correspond to the transition between continental and oceanic crust within the axis of maximum sediment thickness. This study is aimed at evaluating the petrophysical parameters of reservoir sand of wells in Uzot-field.

\section{MATERIALS AND METHODS}

Description of Study Area: Uzot-field is located at the western Coastal Swamp Depobelt of the onshore Niger Delta Basin, Nigeria (fig 1). The subsurface structure of the field indicates the presence of down-to-basin footwall and hanging wall faults associated with rollover anticlines and horst-block (back-to-back fault) (Omoja and Obiekezie, 2019). Data Collection and analysis: Well log data from sonic, gamma ray, matrix density and resistivity logs from four deep wells in Uzot field were used in the analysis. These 
logs were made available by Shell Petroleum Development Company. The ability of rocks to conduct electrical current is primarily a function of the quantity and salinity of the pore fluid. A highly resistive permeable bed is therefore indicative of high hydrocarbon saturation (Dresser Atlas, 1982). The resistivity logs were therefore first used to identify hydrocarbon or water-bearing zones and hence indicate permeable zones. The various sand bodies were then identified on the gamma ray logs (fig. 2). From these logs, the gamma ray index IGR, Net-to gross, water saturation, Porosity and permeability of the D3100-reservoir sand were calculated.

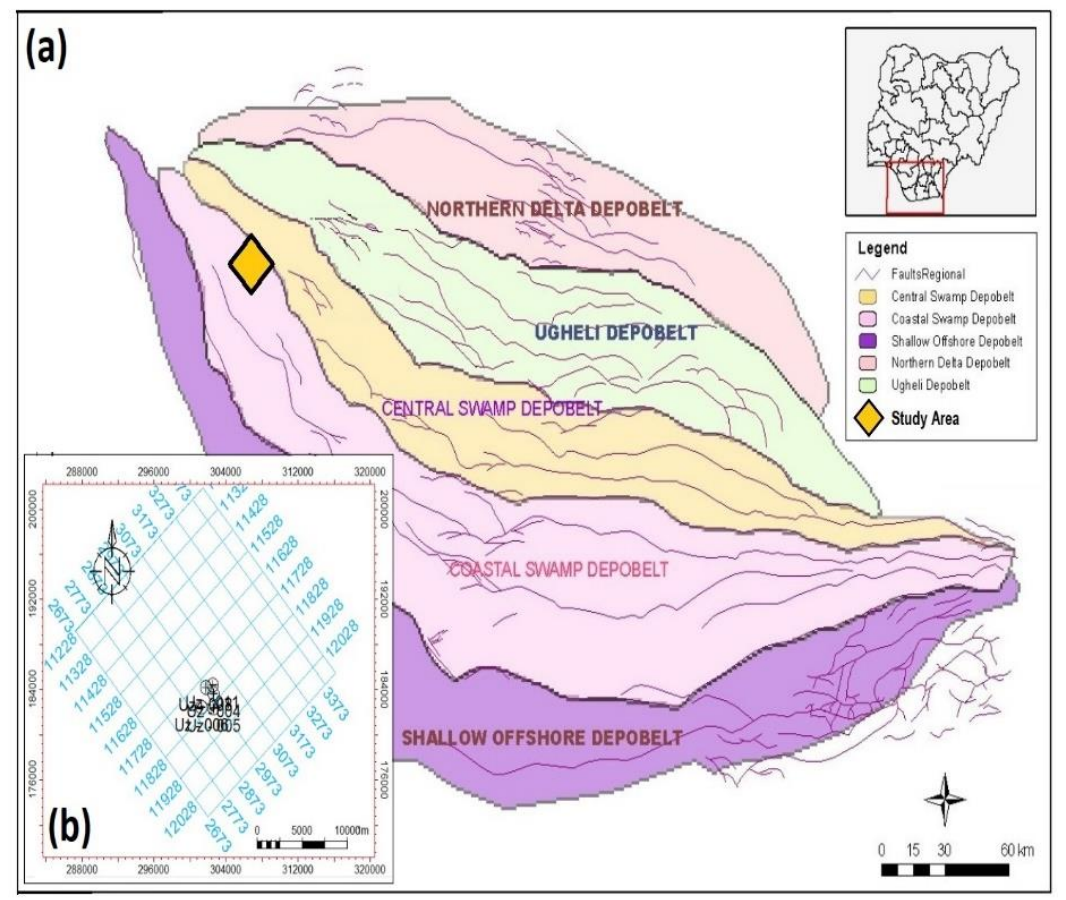

Fig. 1: a) Depobelt map with structural elements, onshore and offshore Niger Delta Basin showing the study area, which lies on the western part of the Costal Swamp Depobelt (modified from Doust and Omatsola, 1990). b) The map of the study is showing wellbore distribution concentrated mainly within the central part.

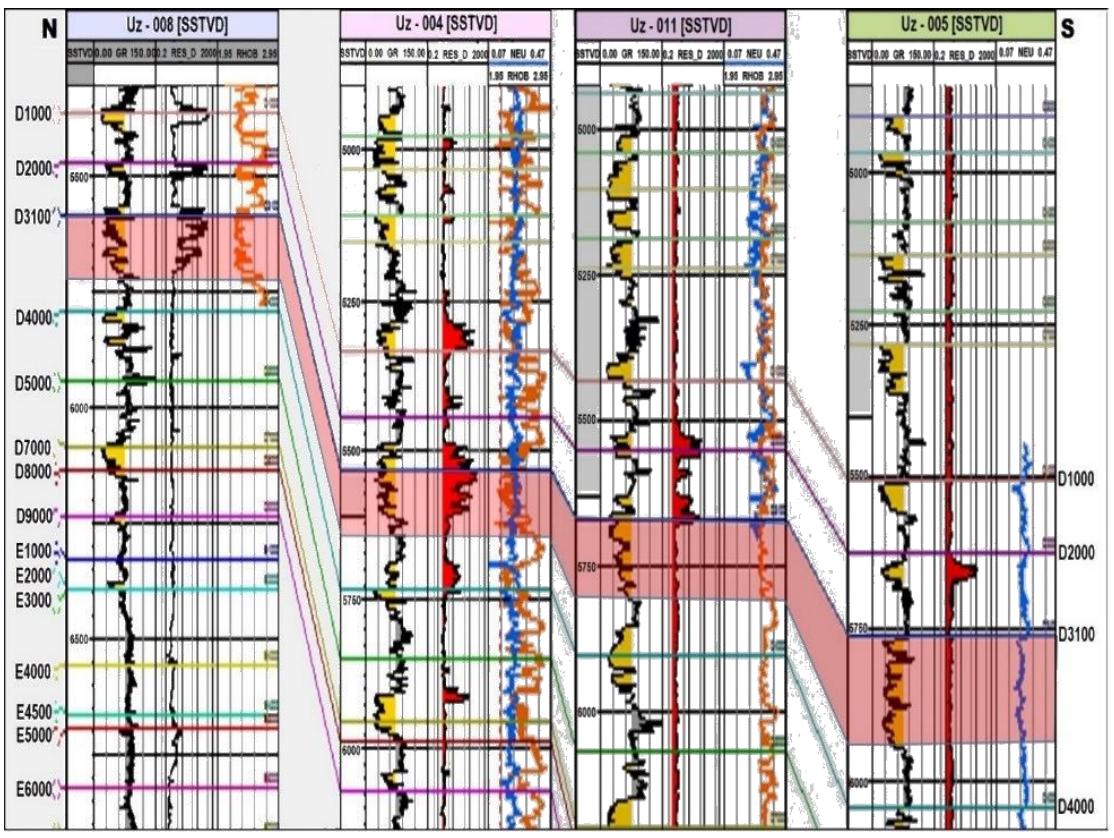

Fig. 2: Well log correlation across representative wells (N-S) showing reservoir of interest (Note: reservoir packages thicken from north to south across wells).

OMOJA, UC; OBIEKEZIE, TN 
These calculations were done using the formulas below (Schlumberger, 1974).

$$
I G R=\frac{G R_{\log }-G R_{\min }}{G R_{\max }-G R_{\min }} \quad 1
$$

Where $G R_{\text {log }}$ is the gamma ray $\log$ reading, $G R_{\text {min }}$ is the minimum value in the gamma ray $\log$ reading (i.e., in the sand packages) and $G R_{\max }$ is the maximum value in the gamma ray $\log$ reading (i.e., in the shale packages).

IGR is called the gamma ray index. The values of IGR obtained were then used to calculate the volume of shale/clay $\left(V_{s h}\right)$ using Larionov's 1969 volume of shale formula for tertiary rocks:

$$
V_{s h}=0.083 \times\left(\left(2^{(3.7 \times I G R)}\right)-1\right) \quad 2
$$

Equation 3.2 is particularly used for tertiary Niger Delta. The volume of shale is used to correct for shale in the reservoir so as to obtain effective porosity.

Porosity is calculated using density or sonic log. Density porosity is calculated using equation 3 .

$$
\phi_{D}=\frac{\int m a-\int b}{\int m a-\int f l} \quad 3
$$

Where $\int m a=$ matrix density (2.65 for Niger Delta), $\int b=$ density $\log$ reading, $\int f l=$ fluid density.

The porosity of shale is also calculated from density $\log$ using

$$
\phi_{\text {shale }}=\frac{\int m a-\int \text { shale }}{\int m a-\int f l} \quad 4
$$

Where $\int$ shale is density of shale

This computed porosity of shale $\phi_{s h}$ is used with density porosity and volume of shale to calculate the effective porosity, $\phi_{E}$ in other to remove that portion of the shale that is associated with the reservoir.

$$
\phi_{E}=\phi_{T}-\left(V_{s h} \times \phi_{s h}\right) \quad 5
$$

Total porosity, $\phi_{T}$ is the average of sonic or density porosity and neutron porosity. In the absence of neutron porosity, density porosity is assumed to be the total porosity.

Water saturation which is another important parameter in petrophysical evaluation is calculated using Archie's 1942 equation for water saturation in uninvaded zone (Archie, 1942).

$$
S_{W}=\sqrt{\frac{a R_{W}}{R_{t} \phi_{E}^{2}}} \quad 6
$$

Where $\mathrm{a}=$ Archie constant, $R_{t}=$ true resistivity (resistivity reading) and $R_{W}=$ resistivity of water given by

$$
R_{W}=R_{o} \phi_{E}^{2} \quad 7
$$

Where $R_{o}$ is the resistivity of $100 \%$ water saturation.

Permeability $(\mathrm{K})$ which measures the ease with which a fluid (gas, oil or water) flows through connecting pore spaces of reservoir rocks was computed using Timur's 1968 equation:

$$
K=8581 \times \frac{\phi_{E}^{4.4}}{S w_{i r r}^{2}} \quad 8
$$

Where $S w_{\text {irr }}$ is the irreducible water saturation and is given by

$$
S w_{i r r}=\sqrt{\frac{F R F}{2000}} \quad 9
$$

Where FRF is the formation resistivity factor. It is given by

$$
F R F=\frac{R_{O}}{R_{W}}
$$

\section{RESULTS AND DISCUSSION}

Computed Petrophysical Parameters: The result of computed petrophysical parameters of D3100 reservoirs sands for wells $\mathrm{Uz} 004, \mathrm{Uz} 005, \mathrm{Uz} 008$ and Uz 011 are shown in Tables 1, 2, 3 and 4 below. Reservoirs in Uz 004 and Uz 008 have porosity ranging from $30-33 \%$ and permeability ranging from $12000-18000$ (md). The values of porosity for these reservoirs indicate that the reservoirs are made up of sandstones. This is in line with the results from Stacher (1995). Unlike the reservoirs in Uz 004 and Uz 008, the reservoirs in $\mathrm{Uz} 005$ and $\mathrm{Uz} 011$ have porosity values ranging from $20-27 \%$ and permeability values ranging from $1000-6000 \mathrm{md}$. The values of porosity for these reservoirs indicate that the reservoirs are made up of Tight sandstones. This is as a result of increase in depth of burial of these reservoir rock since increase in depth of burial of sediments decreases porosity and permeability values. The increase in depth of burial of the reservoir rocks caused reduction in the pore space due to increased overburden expelling pore fluids and this in turn affect the pore fluid production. The low resistivity values at the depth of about 5750ft for $\mathrm{Uz} 005$ and $\mathrm{Uz} 011$ (fig 2) indicate that the reservoir contains mainly water. 
Tables 1: Summary of the petrophysical evaluation of the reservoirs identified in well UZ 004

\begin{tabular}{lllllllllll}
\hline Resevior & Top(ft) & Base $(\mathrm{ft})$ & NTG & Porosity $(\%)$ & $\mathrm{Sw}(\%)$ & $\mathrm{S}_{\mathrm{h}}(\%)$ & $\mathrm{BVW}$ & FRF & Swirr $(\%)$ & $\mathrm{K}(\mathrm{md})$ \\
\hline A & 5540 & 5640 & 0.6400 & 30.10 & 28.80 & 71.20 & 0.083 & 12.33 & 7.70 & 12153 \\
B & 5645 & 5658 & 0.8462 & 32.10 & 32.20 & 67.80 & 0.102 & 9.815 & 7.00 & 12456 \\
\hline
\end{tabular}

Tables 2: Summary of the petrophysical evaluation of the reservoirs identified in well UZ 005

\begin{tabular}{lcccccccccc}
\hline Resevior & Top(ft) & Base(ft) & NTG & $\begin{array}{l}\text { Porosity } \\
(\%)\end{array}$ & Sw(\%) & $\mathrm{S}_{\mathrm{h}}(\%)$ & $\mathrm{BVW}$ & FRF & Swirr $(\%)$ & $\mathrm{K}(\mathrm{md})$ \\
\hline $\mathrm{A}$ & 5750 & 5932 & 0.560 & 27.76 & 88.00 & 12.00 & 0.245 & 13.76 & 8.20 & 5950 \\
\hline
\end{tabular}

Table 3: Summary of the petrophysical evaluation of the reservoirs identified in well UZ 008

\begin{tabular}{lllllllllll}
\hline Resevior & Top(ft) & Base $(\mathrm{ft})$ & NTG & Porosity $(\%)$ & $\mathrm{Sw}(\%)$ & $\mathrm{S}_{\mathrm{h}}(\%)$ & $\mathrm{BVW}$ & $\mathrm{FRF}$ & Swirr $(\%)$ & $\mathrm{K}(\mathrm{md})$ \\
\hline A & 5580 & 5594 & 0.7857 & 31.60 & 19.64 & 80.36 & 0.058 & 10.41 & 7.162 & 12158 \\
B & 5605 & 5642 & 0.7714 & 33.80 & 14.21 & 85.79 & 0.046 & 9.03 & 6.672 & 18089 \\
C & 5668 & 5688 & 0.9000 & 33.30 & 16.53 & 83.47 & 0.055 & 9.11 & 6.738 & 15746 \\
D & 5697 & 5714 & 0.7059 & 33.30 & 40.65 & 59.35 & 0.134 & 9.08 & 6.727 & 15822 \\
\hline
\end{tabular}

Tables 4: Summary of the petrophysical evaluation of the reservoirs identified in well UZ 011

\begin{tabular}{lllllllllll}
\hline Resevior & Top(ft) & Base(ft) & NTG & Porosity $(\%)$ & Sw $(\%)$ & $\mathrm{S}_{\mathrm{h}}(\%)$ & BVW & FRF & Swirr $(\%)$ & $\mathrm{K}(\mathrm{md})$ \\
\hline A & 5682 & 5707 & 0.6000 & 21.40 & 38.60 & 61.40 & 0.080 & 24.78 & 10.90 & 1314 \\
B & 5711 & 5800 & 0.8202 & 25.70 & 80.30 & 19.7 & 0.203 & 15.76 & 8.80 & 3436 \\
\hline
\end{tabular}

The high value of water saturation at that depth also indicate that the reservoirs contain mainly water. This could be as a result of the infiltration of the reservoir by water. From the neutron-density combination for $\mathrm{Uz} 004$ (fig 2), it can be seen that the fluid type for the D3100- reservoirs of $\mathrm{Uz} 004$ is oil.

Conclusion: Evaluation of the petrophysical parameters of Uzot-field for its reservoir's characterization was carried out by careful analysis and interpretation of its well $\log$ s data. The results showed the delineated reservoir units having porosity, permeability and hydrocarbon saturation values indicative of a suitable reservoir quality attributed to the well sorted nature of the sands. These results suggest high hydrocarbon potential and a reservoir system whose performance is considered satisfactory for hydrocarbon production.

Acknowledgments: The authors are grateful to Department of Petroleum Resources (DPR) and PortHarcourt office for granting the permission to obtain the data used for this research work. They thank the Shell Petroleum Development Companies in Nigeria (SPDCN) for provision of the data that was used for this research work. They are also grateful to Schlumberger and ExxonMobil for the provision of the Petrel Software and Workstations, respectively, and also to Chidozie Izuchukwu Princeton Dim and Chukwudike Gabriel Okeugo for their technical contribution to this paper.

\section{REFERENCES}

Archie, GE (1942). The electrical resistivity log as an aid in determining some reservoir characteristics. J. Petrol. Technol. 5: 54-62
Avbovbo, AA (1978), Tertiary lithostratigraphy of Niger Delta: Am. Assoc. Petrol. Geol. Bull 62: 295-300.

Doust, H; Omatsola, E (1990). Niger Delta: In Edwards, JD; Santogrossi, PA (ed) divergent/passive margin basins: Am. Assoc. Petrol. Geol. Bull Memoir 48:201-328.

Dresser Atlas, (1982). Well-logging and interpretation techniques. Dresser Atlas Publication

Ejedawe, J.E (1981). Patterns of incidence of oil reserves in Niger delta basin. AAPG Bulletin. 65:1574-1585.

Evamy, BD; Herebourne, J; Kameling, P; Knap, WA; Molley, FA; Rowlands, PH (1978). Hydrocarbon habitat of Tertiary Niger Delta. Am. Assoc. Petrol. Geol. Bull. 62: 1-39

Hilchie, DW (1990). Wireline: A history of the well logging and perforation business in the oil fields. D. W. Hilchie Inc., Boulder, Colorado, U. S.A. pp. $25-86$.

Larionov, V; (1969). Borehole Radiometry. Nedra, Moscow.

Omoja, UC; Obiekezie, TN (2019) Application of 3D Seismic Attribute Analyses for Hydrocarbon Prospectivity in Uzot-Field, Onshore Niger Delta Basin, Nigeria. International J. of Geop. 2019: 11

Schlumberger, (1974). Log Interpretation Chart, Schlumberger Educational Services, New York. 
Schlumberger, (1996). Log interpretation charts. Schlumberger Well Services, Houston.

Short KC; Stauble AJ (1967). Outline of Geology of the Niger delta. Am. Assoc. Petrol. Geol. Bull. 51: 761-779.

Stacher, P (1995). Present understanding of the Niger Delta hydrocarbon habitat, in Oti, MN; Postma, G (ed) Geology of Deltas: Rotterdam, A.A. Balkema., 257-267.

Timur, A (1968). An investigation of permeability, porosity and residual water saturation relationships for sandstone reservoirs: The $\log$ Analyst, 9(4):8-17.
Tuttle, MLW; Charpentier, RR; Brownfield, ME (1999). The Niger delta petroleum system: Niger delta province, Nigeria, Cameroon, and Equatorial Guinea, Africa: USGS Open-file report 99-50-H: 1-64.

Uguru, CI; Onyeagoro, OU; Sikiru, IO (2002). Permeability modeling for reservoirs in the Niger Delta based on geological descriptions and core data. SIPM Review Report. 4 - 98. 